\title{
Exploring the Contributions of Microfinance Institutions to the Ghanaian Economy: A Study at Takoradi
}

\author{
Daniel Odoom \\ Research Coordinator, Ghana Technology University College, Takoradi Campus \\ Kennedy Oppong Fosu \\ Finance Manager, Ghana Technology University College, Takoradi Campus \\ Kwadwo Ankomah \\ Lecturer, Faculty of IT Business, Ghana Technology University College, Takoradi Campus \\ Marian Birago Amofa \\ MBA Scholar, Ghana Technology University College/Coventry University
}

\section{ABSTRACT}

Microfinance Institutions (MFIs) play an important role in making services available to the financially excluded masses, especially the needy and the informal sector. MFIs do not only have a considerable influence in reducing poverty but are able to do so in a manner that is sustainable. These institutions predominantly are regarded to be critical tools for growth in battling poverty and over-reliance on central and local governments, in several developing nations including Ghana. In spite of the above, MFIs face a number of challenges in Ghana, with the news of collapse of some MFIs which has become a cause for concern to various stakeholders. This tends to create some doubts regarding the role MFIs play in the Ghanaian economy. Using Takoradi as a case, this study sought to examine the views of operators and employees of MFIs with regard to the contributions of the institutions to the economy of Ghana through descriptive survey design in a quantitative research approach. The researchers adopted the purposive and simple random sampling techniques in selecting 114 respondents for the study, with questionnaire as the research instrument. Analytical tools used for the study were frequencies, percentages and an independent sample t-test. The study revealed that in terms of their types based on client base, most microfinance institutions operating in the city targeted SME operators. Also, based on their services, MFIs in the city were grouped into individual lending, group lending, compulsory and voluntary savings, among others. Again, the study found that MFIs in Takoradi contribute variously to the local economy including provision of financial capital to the people; income generation; employment creation; engaging the non-formal economy and providing support for SMEs to grow. Other contributions are in the areas of women empowerment; savings culture, credit facilities, asset creation tools and financial literacy. It is recommended that MFIs collaborate with local authorities including the District Assemblies and Business Advisory Centres to come with measures to ensure penetration into the rural areas in order to improve the conditions of the rural folks.

Keywords: Microfinance Institutions, Ghanaian Economy

DOI: $10.7176 / \mathrm{JESD} / 10-1-09$

\subsection{INTRODUCTION}

As a concept, microfinance is a way to make available financial services to the poor or clients with low income, since they are usually excluded from any traditional financial system and are often regarded as "unbanked" as a result of lack of collateral, stable employment and a verifiable history of credit (Westover, 2008). Armendariz and Morduch (2005: 1) also see microfinance as a collection of banking practices established around the provision of small loans (usually collateral-free) and acceptance of micro savings deposits which, according to Fisher and Sriram (2002), is a product of innovation in the saving and loan mechanism. In essence, microfinance refers to the incorporation of financial needs of individuals into a national mainstream financial system. This sort of movement often relieves those who find it very challenging to have access to finance from the hustle they have to go through before having access to services that can support the growth of their business (Armendariz and Morduch, 2005; Asiama and Osei, 2007).

The World Bank's definition of microfinance states that it involves in comparably small financial transactions and use different procedures to meet the needs of low-income households, micro enterprises, small-scale farmers, and others who do not have access to traditional banking services. Micro-financing involves deposits, loan disbursements, service payments, as well as insurance in smaller quantities as opposed to the main banking sector. Ultimately, it aims at providing the opportunity to becoming self-sufficient by giving a platform to save or borrow money, insurance and a variety of financial services which includes remittances and payments. 
Generally, the concept is meant to provide less privileged individuals and groups with small funds as a means of engaging in productive ventures (Josily, 2006). Microfinance is seen as a tool for development globally. Particularly, it is important to the progress of the economy of Ghana since it provides financial services for the "productive poor" in the informal sector who do not have access to funds for growth and development (Asiama and Osei, 2007). Asiama and Osei (2007) further assert that Microfinance Institutions (MFIs) absorb surplus liquidity in the economy through savings that adds up to investment capital for national development. A research conducted by the International Finance Corporation (IFC) in 2014 revealed more than 130 million people have directly benefited from operations associated with microfinance but only represents approximately 20 percent of the 3 billion people that form the world's poor. The role of MFIs as an alternative way of encouraging and assisting small and medium scale enterprises and entrepreneurship remains essential in economies globally.

A large body of evidence shows that microfinance can have an impact on poverty reduction and the overall economy. Again, there is an emerging body of literature to support the fact that microfinance can impact positively on health, nutritional status and primary school attendance (Morduch and Haley, 2002). According to Simannonitz (2004), microfinance programs are among the most essential interventions in developing countries efforts to reduce poverty. Most MFIs aim at poverty reduction as their missions for which they receive donor funding. Many donor funding is allocated to MFIs which seek to reduce poverty especially among the rural poor. Almost all the MFIs have a mission for the larger society. They aim to reduce poverty, to reach people excluded from financial services to empower women or to promote community solidarity, (Imp-Act Practice Notes, 2005).

Since the past decades, the role of MFIs in reducing poverty has been given much attention in developing economies. The UN in declaring 2005 as the international year of Microcredit stressed on the important part a stable and progressive financial sector played in bringing down poverty in growing economies. Microcredit is the aspect of micro-financing that lends out (Rallens and Ghazenfa, 2005). Apart from credit facilities, MFIs provide other products including savings, insurance, leasing and other money transfer services (Addai, 2010). It is believed that micro-financing is instrumental in community development strategies. Individuals with the opportunity to save, borrow, insurance, and several other financial assistance are much more able to deal with daily situations and exigencies. It has been shown by most econometric researches that microfinance is able to smooth consumption levels and to a recognizable extent lower the urgency to meet basic requirements by selling belongings. Having access to micro insurance reduces the burden of financial emergencies that comes with demise, ailments, and loss of belongings through fire, etc.

Microfinance is no new idea in Ghana because it has been a common practice for people to save and/or take small loans from individuals and groups within the context of self-help to engage in small retail or farming ventures. It began in Ghana in the form of self-help where individuals saved and borrowed small loans from each other (Asiama and Osei, 2007). The PNDC Law 328 of 1991 was therefore put in motion to formalize the setting up of non-banking financial institutions which includes savings and loans companies, credit unions and so on. According to the PNDC Law 328, as amended in 1993, no institution shall carry out non-banking financial activities without being incorporated in the country, having met the minimum capital requirements and granted a license to operate by the Bank of Ghana after successfully going through the licensing application process.

Micro-Finance Institutions (MFIs) play an important part in making services available to the financially excluded masses, especially the needy and the informal sector. Governments and donor agencies consider microfinance as an important strategy for reducing poverty in the growing economies. Women have especially benefited from the various services of MFIs (Parveen, 2009). MFIs' advocates argue that MFIs do not only have a considerable influence in reducing poverty but are able to do so in a manner that is sustainable (Mcguire and Conroy, 2000). Microfinance entities predominantly are regarded to be critical tools for growth in battling poverty and over reliance on central and local governments, in several developing nations including Ghana. It is believed, that microfinance has the ability to proficiently and adequately give sustainable financial services to the less privileged that may generally be left out of the conventional financial system for absence of collateral. These organizations have been helpful tools in expanding people's economic capacity. Through their loan facilities, various entrepreneurs, artisans and apprentices have received start-up funds. This has added to the diminishing weight on the central administration in the areas of job creation, providing credit and overall standard of living. Along these lines, MFIs have been viewed as essential tools in the country's effort at reducing poverty (Asiama and Osei, 2007).

Baten (2009) suggests that MFIs play an instrumental role in the economies of nations. For instance, MFIs remain one of the major contributors in reducing poverty and creating jobs to better the economy (Baten, 2009). In particular, there is overwhelming evidence which substantiates the importance of MFIs on the economy (Morduch and Haley, 2001). Dunn (2005) found that the MFIs contribute to employment and wages of non- 
household employees of the economy. Thus, MFIs remain a potent force in the growth of the economy. According to Morduch and Haley (2001), although MFIs are effective and powerful tool for poverty reduction; they insufficiently penetrated the poorer strata of society. This appears to cast doubts on the overall contribution of MFIs to the economy. Despite the critical role of MFIs in the country, it is widely believed that the industry is struggling in Ghana. For instance, in 2013, 30 microfinance institutions that could not maintain their operations collapsed (Obour, 2013) while seventy had their licenses revoked in 2015 for not conforming to Bank of Ghana regulations (Otoo, 2015). About 100 MFIs collapsed between the years 2013 and 2015 resulting in losses to various clients. The socio-economic effect of these failures and the reported cases of financial irregularities by the likes of Diamond Microfinance (DKM) among others cannot be over-emphasized. Beyond the socioeconomic effects, such situations potentially erode confidence in the activities of MFIs by the already large unbanked population in the country. It is indeed, detrimental to SMEs and other businesses that depend on the services of MFIs in the country. What is more, the collapse of these MFIs presents a huge challenge to the continuing relevance of MFIs to the economy of the country. This is because if MFIs are really important to the economy, then one would expect that adequate measures are put in place to ensure their growth and sustainability. It is against this background that the researchers sought to examine the contributions MFIs to the economy of Ghana in the face of its recent challenges using Takoradi as a case in order to suggest measures for policy decisions.

\subsection{Purpose of the Study}

The study mainly explored the contributions of microfinance institutions to the economy of Ghana using Takoradi as a case.

\subsection{Research Objectives}

The objectives of the study were to:

1. Ascertain the types of microfinance institutions and their products.

2. Examine the contributions of microfinance institutions to the economy of Takoradi.

3. Determine whether or not differences exist in the views of males and females regarding the contributions of microfinance institutions to the economy of Takoradi.

\subsection{Research Hypotheses}

$\mathrm{H}_{\mathrm{o}}$ : There is no significant difference in the views of males and females regarding the contributions of microfinance institutions to the economy of Takoradi.

$\mathrm{H}_{1}$ : There is significant difference in the views of males and females regarding the contributions of microfinance institutions to the economy of Takoradi.

\subsection{OVERVIEW OF LITERATURE}

\subsection{The Concept of Microfinance}

Micro financing provides financial services to self-employed or low income poor people (Asiama and Osei, 2007). Schreiner (2001) is supportive of this school of thought and therefore defines micro financing as "the bid to enhance availability of minor deposits and credit for needy households." Thus, micro financing consists of meeting the financial needs of the less privileged that dwells in rural and urban areas with services such as savings, loans and insurance. Westover (2008) describes it as a way to make available financial services to the poor or clients with low income, since they are usually excluded from any traditional financial system as and are often regarded as "unbanked" as a result of lack of collateral, stable employment and a verifiable history of credit. Armendariz and Morduch (2005: 1) also stated, that a collection of banking practices established around the provision of small loans (usually collateral-free) and acceptance of micro savings deposits is microfinance and that according to Fisher and Sriram (2002) is a product of innovation in the saving and loan mechanism. In another sense, microfinance illustrates the incorporation of financial needs to individuals into a national mainstream financial system. This sort of movement often relieves those who find it very challenging to have access to finance from the hustle they have to go through before having access to services that can support the growth of their business.

According to Marguerite (2001), microfinance operates as a small scale financial service with a focus on providing credit and savings to individuals operating micro enterprises involved in micro-production, recycling, repairing and service provision. In the view of Hagen (2004), microfinance does not only provide financial service to the very poor, but also engage them in productive activities or enable them to grow their small business over a period of time. Today, most microfinance institutions have inculcated an extensive array of services that include offering credits, savings, insurance, money transfer facilities to meet the various financial needs of the less privileged in society. Report from Microfinance Information Exchange (MIX, 2011) also 
describes the diverse financial services aimed at low-income individuals, especially women as microfinance. This literally means that, the creation of Microfinance aims to empower women through the availability of small loans. In this sense, microfinance serves as a catalyst to assist the poor and vulnerable, (particularly women) who are often affected by conditions of loans simply because they do not have collateral.

Likewise, according to a report from the Asian Development Bank ([ADB], 2011), microfinance plays a significant role in both household and the growth of small and medium enterprises, as it provides the platform for enterprises and individuals to have access to financial services including deposits, loans, money transfers and insurance. However, in recent days, the inclusion of insurance to microfinance, which is often refers to as "micro insurance' focus on providing insurance to businesses of small and medium enterprise clients, such that, when there is a default in the repayment of loans and the collapse of businesses, it serves as an option in revamping the businesses.

In Ghana, some may argue, that formalization of microfinance may be relatively new as it began in the 1990s, and during that period, it had direct linkage to women and eradication of poverty. The government of Ghana has made efforts to motivate commercial banks to provide support for micro, small and medium enterprises. In recent times, commercial banks, particularly the local indigenous banks have supported the policy of the Microfinance and have regarded as an approach towards the elimination of poverty and the support of business. The presence of microfinance institution is also focused on supporting small and medium enterprise against emergencies and the ability to recover from shortfalls in an effort to make SMEs sustainable. The components of microfinance are limited in the Ghanaian situation as a result of several factors that include the volatile business environment and the low portfolio of capital. Report from Consultative Group to Assist the Poor (2010) and Helms (2006) have revealed that, services that provide accessibility to finance for the poor, as well as other basic financial services including credits, savings, money transfer and micro insurance is microfinance.

In essence, micro-financing refers to financial services or products that are targeted at the underprivileged in society, with the aim to take them out from poverty and improve on their standard of living. This approach involves savings and providing small credits and in some cases, provides insurance for small business owners as well as prospective entrepreneurs. Following Muhammed Yunu's era, the poor has the opportunity for an improved livelihood, with MF as a tool for raising their standard of living. Banks are now using MF as a marketing vehicle and setting up MFIs with the aim of generating profit. Basically there are two forms of MFIs in terms of their source of funding. Thus MFIs operating with funds received through donations and those operating from funds generated through investment activities. Additionally, micro financing is operated through institutions and it is imperative therefore that microfinance institution is also defined. According to Abubakari (2011), MFIs involve agents and organizations engaged in relatively small financial transactions applying specialized, character based methodologies to serve low-income households, micro enterprises, small farmers, and others who may not have access to the main banking system.

Moreover, microfinance as an economic development approach involves providing financial services, through institutions, to low income clients. Credit, savings and insurance services are some of the services provided by Microfinance Institutions (MFIs). Also provided are social intermediation services such as training and education, organizational support, health and skills in line with their development objectives. Further, these are organizations, engaged in disbursing micro credit and other financial services to poor and less privileged borrowers for activities that generate income and self-employ. MFI's do not form part of the formal banking sector. They are usually referred to as Non-Bank Financial Institutions (NBFI). Micro savings enables needy persons keep safe money and other valuable items whiles earning interest. Thus, future gains on current savings (Arytery, 2008). Micro insurance, on the other hand, refers to providing insurance to low income persons. Less privileged households can be vulnerable to risk, with regards to common occurrences such as illness and accidents as well as uncommon ones. MFIs can play a major part in shielding low income earners facing such vulnerabilities by providing credit for more earning opportunities and by delivering savings services that can accumulate funds to be relied upon in the event of contingencies. The terms microcredit and microfinance are often used interchangeably, but it is necessary to draw attention to the difference between them since both terms are often misused. Hermes and Lensink (2007) asserts that "microcredit refers to micro credit, whereas microfinance is used where loans are supplemented with other financial services such as savings and insurance" by MFIs and NGOs. Therefore, microcredit is a subset of microfinance in that it involves the provision of credit to the poor, whilst microfinance add on non-credit financial services such as savings, insurance, pensions and payment services (Asiama and Osei, 2007).

Additionally, micro financing has different features, which according to Mohammed and Mohammed (2007) "entails micro quantities of loans disbursed to a person or body of individuals enabling them pursue ventures that 
can generate income". Also micro financing includes small amounts of savings which over a period serves as a source of security for less privileged homes and helps in gathering enough capital to address constraints". Again, "disbursed funds are for short periods usually not more than a year. Payments made over a period include the main amount borrowed in addition to interest accrued and paid weekly". Finally, "clients' time and money is saved when there's easy access to the microfinance intermediary giving the intermediary the financial and social standing of customers" (Mohammed and Mohammed, 2007). Unlike traditional banks, customers do not have to go through lengthy procedures in their application for funds. Collateral may not be required. Alternative methods are used, for instance, the potential cash flow of the said venture for which client is requesting funds is analyzed. Some lenders may give loans of large size at comparably lower interest rates since they may be less costly. Dutiful customers become candidates for higher amounts for repeat loans.

\subsection{Approaches of Microfinance}

Scholars have grouped approaches to micro-financing mainly into two. They are the welfarist approach, also known as direct credit, and the institutionalist approach, also called the financial market approach (Morduch, 2000).

\subsubsection{Welfarist Approach}

Under this approach, the focus is on the demand side. In other words, emphasis is on clients. The welfarist is of the view that microcredit schemes should be subsidized as a way of lowering cost on microfinance institutions. Then, they can in effect lower interests on disbursed loans (Morduch, 2000). Bhatt and Tang (2001) pointed out, that MFI's performance is assessed through household studies with focus on the living standard of the individuals; quantity of savings accounts, quantity of loans, improvement in productivity, incomes, accumulation of capital, social services like education, health and expenditure on food. Welfarists argue that it is possible for MFIs to be sustainable even when the institutionalist description of self-sufficiency is not applied (Bhatt \& Tang, 2001). They argue further that gifts, like subsidies, from donors are a form of equity, therefore donors can be seen as investors. However, unlike in publicly traded firms where investors who purchase equity are expectant of monetary returns, MFI donors do not. Rather, donor-investors receive innate gains. Comparably, they are likened to equity investors who, though the expected risk-adjusted return of the socially responsible fund may be below that of an index fund, invest in socially responsible funds. The innate gain of not putting investments in companies they regard obnoxious, and also being regarded as humanitarian or philanthropist hence socially responsible are some of the reasons these fund investors will find acceptable lower prospective gains.

\subsubsection{Institutionalist Approach}

Institutionalists argue that MFIs with their revenues must be able to cover their costs. They believe being selfsufficient enables MFIs to be sustainable in the long-run, which enables higher levels of eradicating poverty in the long-run (Brau and Woller, 2010). Also, this school of thought criticizes subsidizing microcredit programs since it results in increased unpaid rates and transaction costs that have failed many of these programs. They argue that subsidies result to an inefficient allocation of financial resources for MFIs, so it is not sustainable for them to be subsidized. The economists in favor of this view assert that the assumptions of the welfarists is wrong when they argue, that since clients are not creditworthy and do not save, the interest rate on repayments should be low, and that commercial banks could not survive in rural areas due to the high costs of offering financial services to poor households.

The assertion of this school of thought that being self-sufficient is a necessity for sustainable MFIs may seem indefensible till it is recognized that there seem to exist an exchange between self-adequacy and targeting (Hermes N. et al. 2008). Most of the MFIs that have shown to be self-adequate attended to borrowers who fell either slightly above or below the poverty line in their various countries (Morduch, 2000). These MFIs, by applying economies of scale are able to extend much bigger credits to the less privileged. Supporters of subsidization place a lot more societal burden on consumption by the needy, assuming a hypersensitive credit demand to rate of interest, low influence of interest rates on gains, averagely high returns on investments by less privileged homes, and minimal or helpful spillovers onto other lenders. Brau and Woller (2010) having reviewed 350 published articles in various journals, they observed, that an institutionist paradigm dominates the microfinance industry. Also, according to Ashfaq Ahmad Khan (2008) microfinance (commercialized) is gradually losing its identity by evading its original social service responsibility, hence, a paradigm shift in its delivery models, target audience and mission.

\subsection{Aim of Microfinance}

Microfinance has been and was meant to be a diversion from the formal banking sector to provide assistance to clients who lack access to commercial banking institutions. Presently, the attention of micro financing no longer 
dwells only on credit for investment in small and micro ventures. The focus rests on various demands of customers, the broader financial ecosystem and the transformational nature of technology (World Bank Handbook on Microfinance, 2013). Thus, in addition to fighting poverty, to create institutions that focuses on the following processes as well:

i. Microfinance aims to make provision for technical guidance to client or group of individuals on how to maintain their accounts and savings. In this sense, beneficiaries are provided with advice and options based on how to enhance their business growths such that they benefit from bigger loans in the future.

ii. Microfinance also aims at helping individuals in making savings to the bank as a group instead of doing saving as a single person. When money has been save, the beneficiaries have the chance to get loans easily from the bank to facilitate the growth of their business activities. Most often, peer pressure serve as a key to sustainable accessibility to credit facility, since it will be less expensive when dealing with group.

iii. Microfinance also focuses on activities that provide the platform where the people improve on their financial status. This is because, microfinance institutions nowadays advice potential entrepreneurs and business owners on loan management and business advisory.

iv. Moreover, microfinance provides variety of purposes, especially when it comes to the development of micro enterprises. According to Anyanwu (2004), microfinance institutions in Africa and other LDCs are the main source of finance for microenterprises. Apart from the variety of products, the mode of implementation, such as providing credit even without collateral is a boost for most microenterprises unlike practices of the traditional banks which is restrictive. Such that the majority of the economically active population that is employed in the informal sector are restricted by the main sector.

v. In addition to the above, microfinance often target women (and the vulnerable) as a way of empowering them to make a living. With the accessibility to loans for start-ups, these women are able to enhance their standard of living and therefore contribute significantly to the society and the economy at large. Making loans accessible to women is one trait of microfinance as portrayed by the Grameen Bank where according to Todaro and Smith (2009), about 97 percent of Grameen Bank's customers are poor women. Empowering women economically promotes and benefits a country's economy as a whole. There is evidence across the world to portray this fact, for instance, in India, giving power to women at the local level led to greater provision of public goods, such as water and sanitation, which mattered more to women (Beaman et al. 2011). Thus, empowering women is smart economics.

\subsection{Contributions of Microfinance Institutions}

Micro-Finance Institutions (MFIs) perform an important part in providing services to the masses, the needy and informal sector with the potential of improving the lives of beneficiaries (Muntambanadzo et al., 2013). Some of the contributions made include provision of capital, providing employment, developing capacity, developing communities, women empowerment. Indeed, poverty eradication remains at the core of MFI engagements and activities. Providing capital towards the economic and productive ventures of the poor is a major step in achieving this goal. Capital is provided in a couple of ways. Providing small credits and other intermediation services like training and supporting the less-privileged to venture in productive activities (Bishnoi, 2015; Muhammad, 2010). It is believed that provision of material capital to the less privileged strengthens their sense of dignity which empowers them to contribute to the society and economy. Also, providing capital can be in the form of creating opportunities for micro savings. Such savings, accumulated over time can be used as start-up capital. Accumulated savings can at times be used as collateral based upon which a larger amount is given to the saver as loan. Whatever the form of savings, the habit of savings is developed and reduces the level of the unbanked in the economy, which will have a long term effect on reducing poverty. The poor need savings services that allow them to deposit small, variable amounts frequently, and to access larger sums in the short, medium, or long term (Rutherford, 2009). Like everyone else, they demand a portfolio of savings products that offer differing terms of loan access and returns (CGAP 2005).

MFIs also create employment opportunities to the people. In the views of Roodman and Qureshi (2006), people should not lose sight of the fact that commercially successful MFIs are remarkable organizations which employ various people at tasks once not regarded. Good jobs created by successful MFIs have considerable multiplier effects. People are able to live sustainable lives and not be a burden on society and the government, through direct job opportunities for the skilled and unskilled; hence, reducing rate of unemployment and social delinquents. Also in providing capital, beneficiaries of micro loans are enabled to generate and in some cases expand their economic ventures. Therefore, microfinance is a financially sustainable instrument that has the 
ability to provide capital and ensure sustainability and growth in the private informal sector (Boateng et al., 2015). Sometimes MFIs will require several skilled personnel to run their various units especially, for an institution with branches.

Again, MFIs contribute to the economies of nations through capacity building. The efforts of MFIs geared towards developing capacity include projects and operations with the aim of developing both institutional and human resource capability in order to be more satisfactory in their service to their increasing customer-base and at the same time become functionally and economically sustained (Friends Consult, 2015) Accordingly, MFIs are able to start projects that complements the capacity of their customers in loan management, customer care, pricing, marketing and credit sales, as well as social and community issues. This manifests especially, at group levels, where customers are encouraged to be in groups to undergo training.

Additionally, MFIs promote community development especially in the rural areas. The relation that exists between outreach and financial self-sufficiency (FSS) of microfinance institutions (MFIs) is well studied, yet little is understood about the relation between broader corporate social responsibility (CSR) measures of MFIs and their financial self-sufficiency (FSS). Hoepner et al. (2011) have stated that regarding microfinance, social promise, the CSR-FSS relation is very important. They continue to explain how crucial corporate social responsibility can drive MFI's progress financially. MFI investors and policy makers seem well informed in devoting attention to MFIs' corporate social responsibility. For some of the support given to community based establishments such as schools, police stations, boreholes and so on, where they have been either renovated or provided anew. Additionally, there have been medical bills of patients that have been fully paid by some MFIs.

Finally, MFIs have and continue to play an important role in women empowerment. According to Cheston and Kuhn (2001), MF has been used to support approaches of empowering women with skills, literacy and socio economic rights in on-farm and off-farm employment. With recognition to girls and women who receive less academic education than boys in the rural areas with skills and employment opportunities that can enable them cater for themselves.

\subsection{The Evolution of Microfinance in Ghana}

Microfinance concept is not new in Ghana. Locally within the context of self-help, people have made savings with and collected micro credits from persons and groups to commence productive ventures. Traditionally, people have saved with and taken small loans from individuals and groups as part of self-help to start businesses or any ventures. There is evidence that suggests that in the Northern Region of Ghana in 1955, Canadian Catholic Missionaries were the first to set up a Credit Union in Africa (Amoah, 2008; Asiama and Osei, 2007). Although it is a part of the recent microfinance schemes, it is believed susu had its origin in the early 1900s in Nigeria and spread to Ghana.

Successive governments have instituted various financial sector policies and programs which have influenced the context for development of microfinance sector activities especially within the informal economy. They include:

- Provision of subsidized credits in the 1950s;

- $\quad$ Establishment of the Agricultural Development Bank in 1965;

- Establishment of Rural and Community Banks (RCBs), and the subsequent introduction of regulations such as commercial banks in the 1970 s and early 1980 s, being required to set aside $20 \%$ of total portfolio, to promote lending to agriculture and small scale industries;

- $\quad$ The promulgation of PNDC Law 328 to allow the establishment of different categories of non-bank financial institutions, including savings and loans companies, and credit unions.

There are three main categories of MFIs in Ghana. They include formal suppliers, semi-formal suppliers and informal suppliers. Formal suppliers may include rural and community banks, savings and loans companies, as well as some development and commercial banks. Semi-formal suppliers also include Financial NonGovernmental Organizations (FNGOs), Credit Unions, and Cooperatives. Again, informal suppliers consist of susu collectors and clubs, rotating and accumulating savings and credit associations (ROSCAs and ASCAs), traders, moneylenders and other individuals (Bank of Ghana [BOG], (2007).

\subsection{RESEARCH METHODOLOGY}

This study adopted the quantitative research approach. The choice of this approach is necessitated by the nature of the data to be analyzed, and the availability of respondents. The descriptive survey design was used in this study. Aggarwal (2008) explains descriptive research as devoted to gathering information on current situations 
with the aim of describing and interpreting. Descriptive research design is chosen because it is suitable for observing, describing, answering the "what is going on?" and documenting the aspects of circumstances. Shuttleworth (2013) explains that descriptive research designs involve observation and description of the behavior of a subject without influencing it. The population for this study includes all employees, managers and assistant managers of MFIs in Takoradi. Purposive sampling was used in selecting microfinance companies licensed by the Bank of Ghana. Thus, the list of licensed microfinance institutions in general compliance with Bank of Ghana's guidelines, located in Takoradi as listed on the central bank's website as at July 2018. There were sixteen (16) licensed MFIs in the city namely, Af Microfinance Company Limited, A-Star Microfinance Limited, Cashpoint Microfinance Limited, Coastal Commerce Microfinance Limited, Daily Capital Microfinance Limited, Donewealth Microfinance Limited, and Ebenezer Microfinance Company Limited. Others are First Rate Microfinance Limited, Loan Line Microfinance Limited, Mallon Microfinance Company Limited, Oye Microfinance Limited, Premier Microfinance Limited, Rogai Microfinance Limited, Startwell Microfinance Company Limited, Unik Life Microfinance Limited and Yaalex Microfinance Limited. With a population of 160 staff members, 114 of them were involved in the study based on Yamane's (1967) sample size determination formula. A set of questionnaire made up of close-ended items was used for data collection. The researchers depended on frequencies, percentages and an independent sample t-test as the analytical tools for the study.

\section{RESULTS AND DISCUSSION}

This section presents the results and discussion of the study, beginning with the background features of the respondents, followed by the findings based on the main research objectives and hypotheses. The sex distribution of the respondents showed that 52.6 percent were males whilst 47.4 percent were females. This means that the majority $(52.6 \%)$ of the respondents were males. This manifestation could be explained by the fact that generally males have relatively higher educational qualifications than females in Ghana. This enables males to have upper hand over females when it comes to employment in the formal sector. With regard to the age distribution of respondents, it was found that 19.3 percent were below 25 years whilst 25.4 percent were between 25 and 29 years as shown in Table 1.

Table 1: Age of Respondents

\begin{tabular}{lcc}
\hline Age (Years) & Frequency & Percentage \\
\hline Below 25 & 22 & 19.3 \\
$25-29$ & 29 & 25.4 \\
$30-34$ & 35 & 30.7 \\
$35-39$ & 14 & 12.3 \\
$40-44$ & 8 & 7.0 \\
Above 44 & 6 & 5.3 \\
\hline Total & 114 & 100 \\
\hline
\end{tabular}

Source: Fieldwork, 2018

Also, from Table 1, it is clear that 30.7 percent of the respondents were between 30 and 34 years, with only 5.3 percent of them above 44 years. It is evident that most (68.4\%) of the respondents aged between 25 and 39 years.

On the marital status of respondents, the researchers observed that 40.4 percent of them were single, 49.1 percent had married whilst 7.0 percent had divorced. What is of huge importance is the fact that the majority $(56.1 \%)$ of the respondents were either married or at least had married before as seen from Table 2.

Table 2: Marital Status of Respondents

\begin{tabular}{lcc}
\hline Marital Status & Frequency & Percentage \\
\hline Single & 46 & 40.4 \\
Married & 56 & 49.1 \\
Divorced & 8 & 7.0 \\
Widowed & 4 & 3.5 \\
\hline Total & 114 & 100 \\
\hline
\end{tabular}

Source: Fieldwork, 2018

Again, the researchers looked at the years of operation of the MFIs involved in the study. With this, the researchers found that out the 16 MFIs in Takoradi involved in the study, 10 of them had been in operation for 510 years, four had operated for 11-15 years, whereas the remaining two had existed for less than five years. From Table 3, it can be stated that the majority $(62.5 \%)$ of the MFIs had existed between 5 and 10 years. Besides, it is 
fair to posit that most of the MFIs were in their mid-stages and would have to work hard to sustain their activities and continuing relevance in the industry.

Table 3: Years of operation by Microfinance Institutions

\begin{tabular}{|l|c|c|}
\hline Years of Operation & Number of MFIs & Percentage \\
\hline Less than 5 years & 2 & 12.5 \\
\hline 5 to 10 years & 10 & 62.5 \\
\hline 11-15 years & 4 & 25.0 \\
\hline Total & 16 & 100 \\
\hline
\end{tabular}

Source: Fieldwork, 2018

The first research objective sought to ascertain the types of microfinance institutions operating in the city. In addressing this objective, the researchers took cognizance of two factors, namely the client base of the MFIs as well as the services they provided. The results on the major client base of the MFIs are displayed in Table 4 . From Table 4, it is clear that 56.3 percent of the MFIs in Takoradi targeted SMEs, 18.7 percent targeted individuals, while 12.5 percent targeted large scale entrepreneur. The criticality of this revelation finds expression in the fact that the majority (56.3\%) of the MFIs had SMEs as their client base. Many of the operators of the SMEs were in the informal sector of the economy who were engaged in variety of activities. This finding resonates with the position held by Maruthi et al. (2011) that microfinance is an important determinant of SMEs' growth globally. Maruthi et al. (2011) discovered that globally, microfinance remains a principal determinant of growth for SMEs. Besides, according to International Finance Corporation (2014), MFIs tend to serve very small enterprise operators with some common characteristics which vary from country and sector. They may include a relatively low level of formalization, record keeping and that is somewhat informal and "in house". However, Olowe et al. (2013) caution that high level rate of interest, collateral security and frequency of loan repayment may reduce the rate of expansion of SMEs across various parts of the world.

Table 4: Type of Microfinance Institutions in Takoradi based on their client base

\begin{tabular}{|l|l|l|}
\hline Clients & Frequency & Percentage \\
\hline Individuals & 3 & 18.7 \\
\hline Families & 2 & 12.5 \\
\hline SMEs & 9 & 56.3 \\
\hline Large scale entrepreneurs & 2 & 12.5 \\
\hline Total & 16 & 100 \\
\hline
\end{tabular}

Source: Fieldwork, 2018

Also, based on their services, MFIs in the city were categorized under thirteen types. From The study found that the types of MFIs in the city include individual lending, group lending, compulsory and voluntary savings, and micro insurance MFIs. Other types of MFIs based on the services are education and funeral loans, loan management advice, financial and bookkeeping advice. All of the MFIs indicated they provide individual or personal loans. However, only 12 of the MFIs provide group loans and a peer group monitoring system. Again, three institutions provide collateral free lending systems which enable customers to borrow if they have a good account with the MFI, thus a character-based lending. Also, eight of them have special accounts which require compulsory saving and all 16 MFIs surveyed allowed for voluntary savings. Only five of the institutions provided micro-insurance services and 12 provided other forms of loans including education and funeral loans. Whilst five of the MFIs provided loan management advice, three of them were providing business advisory services. However, none of the MFIs provided rural outreach, business training and mobile banking services. Although MFIs in Takoradi were offering variety of services they need to be innovative to ensure that clients' needs and specific situations are taken care in the industry. According to the findings of Adjei (2010), MFIs need to be innovative with various forms of products and services necessary and appropriate for clients' situation and needs. Oji (2006) also submits that partnering with relevant technology, enterprise development and skills training institutions to provide client-focus skills training to their clients could be of immense help for clients to properly grow and develop their enterprises.

The second objective of this study examined the views of respondents on the contribution of MFI to the economy of Takoradi. Respondents were asked to assess the contributions MFIs made in the local economy and therefore the Ghanaian economy by extension. In doing so, researchers asked the respondents to rank the contributions based on a 3 point measurement scale. 1 represents Low (L) contribution, 2 represents Moderate 
(M) contribution, and 3 represents High $(\mathrm{H})$ contribution to the economy. The results from the questionnaire are displayed in Table 5. Several issues regarding the contributions of MFIs to the local economy were discussed as found in literature. They include provision of financial security to people; income generation; employment creation; enabling individuals to plan for the future; and engaging the non-formal economy. Other issues examined are support SMEs; women empowerment; development of rural areas; an investment opportunity; savings culture; and financial literacy.

Table 5: Views of Respondents on the Contribution of MFIs to the Economy of Takoradi

\begin{tabular}{|l|l|l|l|l|}
\hline Statement & Low (\%) & $\begin{array}{l}\text { Moderate } \\
(\%)\end{array}$ & High (\%) & Total (\%) \\
\hline Provides financial capital to people & 7.9 & 40.2 & 51.9 & 100 \\
\hline Income generation & 7.9 & 52.8 & 39.3 & 100 \\
\hline Provision of employment & 17.5 & 30.5 & 52 & 100 \\
\hline Enables individuals plan for the future & 31.5 & 41.8 & 26.7 & 100 \\
\hline Engaging individuals in the non-formal economy & 11.1 & 22 & 66.9 & 100 \\
\hline Support SMEs to grow & 10.1 & 31.2 & 58.7 & 100 \\
\hline Women Empowerment & 22 & 22.9 & 55.1 & 100 \\
\hline Development of rural areas & 51.8 & 27.8 & 20.4 & 100 \\
\hline Asset creation tools & 12.5 & 30.5 & 57 & 100 \\
\hline Savings culture & 11.1 & 20 & 68.9 & 100 \\
\hline Provision of credits at low interest rate & 22 & 25.9 & 52.1 & 100 \\
\hline Financial Literacy & 22 & 26.9 & 100 \\
\hline
\end{tabular}

Source: Fieldwork, 2018

On the issue of MFIs in the city contributing to the provision of financial capital of people, 51.9 percent said it was high whilst 7.9 percent saw it as low as seen in Table 5. The implication is that MFIs in Takoradi are making strides in terms of their contribution towards financial capital of the people in the city. Moss, as cited in Zhaung (2009), opines that financial systems such as the stock markets cannot be expected to provide capital for the poor or even small companies. Moss asserts that local community banks are better positioned to serve such clients. To this end, Moss expects that governments which want to create an enabling environment for the private sector should focus on creating a legal and financial framework to promote access to credit across the spectrum of demand. It is within this context that microfinance becomes appropriate on the basis that most MFIs often cite poverty reduction as a key component in their operational issues. Thoma (2009) maintains that developing countries need microfinance to meet many of their basic financial needs. Boateng and Agyei (2013) believe that when micro-finance is used effectively government, it will help serve as source of capital for micro enterprises and contribute positively to GDP.

Again, from Table 5, it is clear that 52.8 percent of the respondents ranked MFIs' contribution to income generation in the economy as moderate whilst 39.3 percent ranked it as high. This means that quite the majority $(52.8 \%)$ of the respondents were of the view that MFIs had contributed moderately to the income generation among the populace. The present study is vital in the face of the expectations of Ruben (2007). In the views of Ruben (2007), MFIs play an important role enabling individuals in the society to generate income and eventually become self-reliant. In their research, Chua et al. (2000) noticed that the influence of microfinance services on income depends on the original abilities of the household and for how long they have patronized the institution.

Additionally, the researchers found that in terms of provision of employment MFIs are ranked as high. This was supported by 52 percent of the respondents who stated that MFIs' contribution to employment creation in Takoradi is high. The finding does not depart from the contention of Roodman and Qureshi (2006). According to the authors, society should not be in oblivion regarding the fact that commercially viable MFIs are help the economy by employing various people for diverse tasks. These jobs created by MFIs, when sustained, have considerable multiplier effects on the overall economy. According to Ruben (2007), credit programs of MFIs can offer the poor access to small amounts of capital which can be used to set up self-employment projects. Boateng 
and Agyei (2013) indicate that when micro-finance is considered seriously by government, it will help create employment and contribute to GDP.

Furthermore, on whether or not MFIs in Takoardi were contributing to engaging individuals in the non-formal economy of Ghana, 66.9 percent of the respondents indicated it highly occurred. However, 11.1 percent of the respondents believed such contribution from the MFIs was low in the city. Better still, the study observed that MFIs in Takoradi contribute to the local economy in terms of providing support to SMEs in the city to grow. This view was held by 58.7 percent of the respondents who commented the contribution of MFIs in the area of providing support to SMEs to grow was high. Although MFIs contribute to the growth of SMEs, their support will not automatically grow SMEs. Essentially, entrepreneurial skills and ability are necessary to run successful SMEs and not all potential customers are capable to take on debt (Morduch and Haley, 2001).

Another area where MFIs were seen to be effective in contributing to the local economy is women empowerment. From Table 5, it is succinct that 55.1 percent of the respondents ranked contribution to women empowerment as high as against 22 percent who felt it was low. This finding corroborates that of Cheston and Kuhn (2001). In their observation, Cheston and Kuhn (2001) contended that micro-finance has been a useful tool employed to promote women empowerment. Its usage is deeply rooted in the skills, literacy and socio economic rights in on-farm and off-farm employment given to women. It is widely contended that women have been shown commitment to repay their loans more often and to direct a higher share of enterprise proceeds to their families. Thus, when women are empowered through micro-financing, the largely society stands to benefit. Addai (2017) found that most women depend on family and friends for financial support and that an increase in access to micro-finance will more likely increase the probability of women's economic and social empowerment.

Regarding their contribution to rural development, the study revealed that MFIs contribute lowly. For instance, while 27.8 percent of the respondents said it was high 51.8 percent of them believed it was low. Zingales (2009) sees microfinance as an unproven way to promote development, let alone poverty reduction. Despite this pessimism, Zingales (2009) supports the championing of small banks as having better local knowledge relevant in developing countries.

Concerning asset creation, the findings in Table 5 show that it was high. This view is confirmed 57 percent of the respondents, as opposed to 12.5 percent of them who believed it was low. The respondents believed that MFIs in Takoradi had enabled to create asset for themselves and their households. Micro-financing can relate to both the chronic and to the transitory poor in different ways. This is so because the condition of poverty finds its conventional interpretation in the lack of access by poor households to the assets necessary for a higher standard of income or welfare. Generally, assets are thought of as human (access to education), natural (access to land), physical (access to infrastructure), social (access to networks of obligations) or financial (access to credit) (World Bank 2000).

Other areas where MFIs in Takoradi have contributed to the local economy include individuals in the city to plan for the future; savings culture; provision of credit facilities; and financial literacy. In the views of Khan (2008), credits availability to the needy contributes to the rise of production and output due to a rise in the need for additional financial services (micro-savings and micro-insurance). This tends to affect financial development positively which helps to set the economy on a path of growth. According to Aghion and Morduch (2000), MFIs encourage people to engage in the private sector by providing micro-credit to micro and small scale entrepreneurs. In support, Akanji (2002) states that the less privileged put to good use the credit facilities given them and show commitment in repaying the loans together with the interest. Again, MFIs help people especially the poor to be able to mostly open and run a savings account (Akanji, 2002). There is a wide recognition of the fact that if access to credit facilities is improved, the poor can finance productive activities that will allow income growth, provided there are no other binding inhibitions. Hulme and Mosley, as cited in Ruben (2005) argue that microfinance offers the possibility of credit facilities in times of need and in also the regular savings by clients itself that can be withdrawn. Chen and Snodgrass, as cited in Morduch and Haley (2001), contend that MFIs which focus on savings more than credit tend to reach a smaller proportion of the poorest, and hence have a lower and slower impact on poverty reduction.

\subsection{Testing of Hypotheses}

Hypothesis 1: There is no statistically significant difference in the opinions of males and females with regard to the contributions of MFIs to the economy.

Tables 6 and 7 respectively show the group statistics and independent samples test used in determining the differences between males and females with regard to their views on the contributions of MFIs to the economy. 
The mean scores in Table 6 for the male respondents $(m=62.4)$ is almost the same as the female respondents $(\mathrm{m}=62.9)$.

Table 6: Group Statistics of Gender and Staff Development Challenges

\begin{tabular}{|l|r|r|r|r|}
\hline Sex & N & Mean & Std. Deviation & Std. Error Mean \\
\hline Male & 64 & 62.4219 & 12.56703 & 1.57088 \\
\hline Female & 50 & 62.9000 & 14.69312 & 2.07792 \\
\hline
\end{tabular}

Source: Fieldwork, 2018

A further analysis of the data using an independent-samples t-test (Table 7) indicates that the $p$ value of the Levene's Test (.374) is greater than the level of significance $(0.05)$, therefore equal variances are assumed. The Sig. (2-tailed) value recorded for assumed equal variance (.855) is greater than 0.05 . This means that the result is not statistically significant. Thus, the null hypothesis which states that there is no statistically significant difference in contributions of MFIs according to the gender of respondents is not rejected. This shows that the views of males on the contributions of MFIs to the economy are not different from that of their female counterparts. The magnitude of the difference in means was very negligible (eta squared $=0003$ ).

Table 7: An Independent Sample Test of Gender and Contributions of MFIs to the economy

\begin{tabular}{|l|l|l|l|l|l|l|r|}
\hline \multicolumn{2}{|l|}{$\begin{array}{l}\text { Levene's Test } \\
\text { for Equality of } \\
\text { Variances }\end{array}$} & \multicolumn{2}{|l|}{ t-test for Equality of Means } \\
\hline & F & Sig. & T & Df & $\begin{array}{l}\text { Sig. } \\
(2- \\
\text { tailed })\end{array}$ & $\begin{array}{l}\text { Mean } \\
\text { Diff. }\end{array}$ & $\begin{array}{l}\text { Std. } \\
\text { Diff. }\end{array}$ \\
\hline Equal variances assumed & 1.651 & .201 & -.187 & 112 & .852 & -.47813 & 2.55531 \\
\hline $\begin{array}{l}\text { Equal variances not } \\
\text { assumed }\end{array}$ & & & -.184 & 96.498 & .855 & -.47813 & 2.60488 \\
\hline
\end{tabular}

Source: Fieldwork, 2018

\section{CONCLUSIONS AND RECOMMENDATIONS}

People living in cities and towns whose access to banking services are limited have relied on MFIs to access financial services. MFIs have also taken it upon themselves to extend the financial services to the individuals, small and medium scale entrepreneurs and families unable to access banking services of the formal financial institutions..

The study observed that the types of MFIs can be understood from many angles. However, in terms of client base, most MFIs operating in Takoradi can be classified as those targeting individuals, families, SME operators, among others. Also, based on their services, MFIs in the city were categorized under individual lending, group lending, compulsory and voluntary savings, micro insurance MFIs, among others. Besides, the study established that MFIs in Takoradi had contributed immensely to the local economy in areas including provision of financial capital to the people; income generation; employment creation; and providing support for SMEs to grow. Other areas of contributions are women empowerment; savings culture, credit facilities, asset creation tools and financial literacy. The study recommends that MFIs should arrange for mechanisms to improve the business skills of clients. Additionally, they must stick to the core objectives of the industry and also give employees the needed skills and knowledge to work, for all levels, from senior level to junior level. Finally, MFIs should collaborate with local authorities to devise measures to rope in those in the neighboring rural areas of Takoardi in their financial services.

Government must pay attention to microfinance sector and set up policies to regularly monitor the activities in the sector.

\section{REFERENCES}

Abubakari (2011). Transformation Building of Micro-Entrepreneurs: A conceptual Model. World Academy of Science, Engineering and Technology. Available at: www.waset.org [Assessed on 5th Aug 2018].

Abuddi, F. (2005). Operation of SACCOs in Tanzania. Unpublished MA Dissertation, University of Dar es Salaam. 
Addai, B. (2017). Women Empowerment through Microfinance: Empirical Evidence from Ghana. Journal of Finance and Accounting, 5(1), 1-11.

Adjei, J.K. (2010). Microfinance and Poverty Reduction: The experience of Ghana. Accra: Bold Communications Limited.

Aggarwal, Y. P. (2008). Meaning of the term-descriptive survey research method'. International Journal of Transformations in Business Management, 1.

Alemu, K. T. (2008). Microfinance as a Strategy for Poverty Reduction. The Hague Netherlands

Anyanwu, C. M. (2004). Microfinance Institutions in Nigeria. Policy, practice and potential Nigeria. Central Bank of Nigeria Research Paper, 1-31.

Asiama, J. and Osei, V. (2007). A Note on Microfinance in Ghana. Bank of Ghana. Available at: https://www.bog.gov.gh/privatecontent/Research/Working\%20Papers/Microfinancing (1).pdf. [Assessed on 5th July 2018].

Beck, T., Levine, R. and Loayza, N. (2000). Finance and the sources of growth. Journal of Financial Economics, $58,261-300$

Bhatt, N. and Tang, S. (2001). Delivering Microfinance in Developing Countries: Controversies and Policy Perspectives. Policy Studies Journal, 29(2), 319-333.

Bichanga, W. O. and Aseya, L. (2013). Causes of loan default within Microfinance institutions in Kenya. Interdisciplianary journal of contemporary research in Business, 4(12).

Birley, S. and Westhead, P. (1990). Growth and performance contrasts between types of small firms. Strategic Management Journal, 11(7), 535-557.

Boateng, I. and Agyei, A. (2013). Microfinance in Ghana: Development, Success Factors and Challenges. International Journal of Academic Research in Accounting, Finance and Management Sciences, 3(4), $153-160$.

Brau, J. C. and Woller, G. M. (2010). Microfinance: A Comprehensive Review of the Existing Literature. The Journal of Entrepreneurial Finance \& Business Ventures, 9, 1-27.

Che Yeon-Koo (2002). Joint Liability and Peer Monitoring under Group Lending. Contributions to Theoretical Economics, 2(1).

Dunn, E. (2005). Impacts of Microcredit on Clients in Bosnia and Herzegovina. Foundation for Sustainable Development of the Federation of Bosnia and Herzegvonia and Republika Srpska Development and Employment Foundation.

Dunford, C (2006) Evidence of Microfinance's Contribution to Achieving the Millinium Development goals. Freedom From Hunger, U. S. A

Daley-Harris, S. (2005). State of the Microcredit Summit Campaign Report.

GHAMFIN (2016). About GHAMFIN. Available at: http://www.ghamfin.org/about-ghamfin/ [Assessed on $15^{\text {th }}$ July, 2018]

Hague, M.S. (2010). The Microfinance Initiatives for Poverty Alleviation. Rhetoric and Reality in Bangladesh, presentation for requirement of the $\mathrm{PhD}$, The school of Biosphere Science, Bangladesh.

Hermes, N., Lensink R. and Meesters, A. (2008). Outreach and efficiency of microfinance institutions. SSRN Working Paper Series. Available at: http://dx.doi.org/10.2139/ssrn.1143925. [Assessed on $5^{\text {th }}$ August, 2018].

Ian, S. (2009). Freedom from Want. Kumarin Press.International Finance Corporation (2014). Experiences of microfinance institutions serving very small to small enterprises in Latin America. Pennsylvania Avenue, N.W. Washington, D.C. 20433. www.ifc.org.

Kumah A. and Boachie W. K. (2016). American Scientific Research Journal for Engineering, Technology, and Sciences (ASRJETS), 26(3), 188-201.

Latham, B. (2007). Sampling: What is it? Quantitative Research Methods. Texas Tech University. Economics Department Working Paper, No. 280.

Marguerite, R., (2001). The Microfinance Revolution, Sustainable finance for the poor Washington DC, 20433 USA. Library of Congress cataloging.

Maruthi R. P., Smith G. \& Laxmi K.S. (2011). Emergency and Impact of Micro-Finance on Indian Scenario. KKIMRC IJRFA (1).

Mnenwa, R., and Maliti, E., (2005). Assessing the Institutional Framework for promoting the Growth of SMEs in Tanzania: The case of Dar es Salaam, Repoa Report 08.6, and Blackfin Ltd.

Mnenwa,R. and Maliti, E. (2008). The Role of Small Business in Poverty Alleviation: The case of Dar es Salaam, Tanzania. Research Report of REPOA 8(2), Mkuki Na Nyota, Tanzania.

Morduch, J. (2000). The Microfinance Schism. World Development 28, 617-629.

Morduch, J. and Haley, B. (2002): Analysis of the Effects of Microfinance on Poverty Reduction. Wagner Working Paper 1,014, New York: New York University 
Mosley, P. (2001). "Microfinance and Poverty in Bolivia” Journal of Development Studies, Vol 37, No 4, pp 101-132(32), April.

Mturi, M.N. (2009). A Critical Analysis of SIDO Performance in Microfinance Services in Poverty Alleviation. Unpublished MBA Dissertation. The Open University of Tanzania.

Muhammad, S. D. (2010). Microfinance challenges and opportunities in Pakistan. European Journal of Social Sciences, 14(1), 94-97.

Mwakajumba, M. (2005). SACCOs Movement in Tanzania; Paper Presented to central Bank of Tanzania Programs in empowerment of SACCOs in Dar es Salaam, Tanzania.

Mzinga, A.T. (2010). Contribution of corporate Governance Principles on the Performance of SACCOs in Tanzania A case of SACCOs Ilala District Dar es Salaam. Unpublished Dissertation Submitted for the Completion of The Master Degree, The Open University of Tanzania (OUT).

Neville, C. (2007). Introduction to research and research methods. Bradford: Effective Learning Service.

Oji, O. K (2006) Transformation of Microfinance Schemes from Subsistence Living to Small-Scale Enterprises in Nigeria, Analysis of Policies for Integration of Science and Technology into the Clients Activities, UNESCO Policy Paper No 11-2

Olomi, D. and Rutashobya, L., (2000). Entrepreneurship and Small Business Development, Dar es Salaam.

Olomi, D. R. (2006). Policy Dialogue; Seminar Paper on Development in Tanzania Opportunities and Challenges for Rural SMEs.

Olomi, D.R., (2003). Entrepreneurship Motivation in Developing Countries, University of Dar es Salaam.

Onyina, P.A. and Turnell, S. (2013). The Impacts of a Microfinance Lending Scheme on Clients in Ghana. Global Journal of Business Research, 5 (2), 79-88.

Ruben, M (2006) The Promise of Microfinance for Poverty Relief in the Developing World. Retrieved from: http://www.csa.com/discoveryguide/discoveryguides-main php

Saunders, M., Lewis, P. and Thornhill, A. (2012). Research Methods for Business Students. $6^{\text {th }}$ ed. Pearson Education Limited.

Schneider, F. (2002): Size and Measurement of the Informal Economy in 110 Countries Around the World. Retrieved from: http://rru.worldbank.org/Documents/PapersLinks/informal_economy

Shreiner, M. (2001). A cost-effective analysis of the Grameen Bank of Bangladesh. Center for Social Development Working Paper, 99-5.

Shuttleworth, M. (2013). Research Design. Available at: http://explorable.com/descriptive-research-design. [Accessed on $13^{\text {th }}$ August 2018].

Simanowitz, A. (2004). Issues in designing effective Microfinance impact assessment systems. Working Paper No. 8. Retrieved from http://www.ids.ac.uk/impact/Publications/publications_workingpapers.html

Singh, P. (2016). Understanding the structure of Microfinance Institutions in India and suggesting a Regulatory Framework.

Stein, P., Goland, T. and Schiff, R. (2010). Two trillion and counting: Assessing the credit gap for MSME in the developing world.

Thoma, M. (2009). Lin RoundTable: Small Banks Need Help. Free Exchange, Economist.com blogs. Retrieved from: http://www.economist.com/blogs/freeexchange/lin roundTable

Thomson (2013). Towards a Micro-level Explanation of Sustainability Transitions: Entrepreneurial Strategies. Working Paper No.11.01, Universite it Utrecht.

Wali, A.M. (2000). Poverty Alleviation and Micro-Credit in Sub-Saharan Africa. International Business Journal, National University, USA.

World Bank (2000). World Development Report. Washington DC

World Bank (2005). World Development Report, Washington DC. The World Bank.

Xiaohui Liu \& Chang Shu, (2002). The Relationship between Financial Development and Economic Growth:

Evidence from China. Studies in Economics and Finance, 20(1), 76-84.

Zingales, L. (2009). Lin RoundTable: Leave Room for Growth. Free Exchange. Retrieved from: http://www.economist.com/blogs/freeexchange/lin_roundTable.www.gufsa.rog.

Zuru, N. L., Hashim, M. K. and Darwina, A. (2016). A Study on the Types of Microfinance Institutions in Nigeria. MAYFEB Journal of Business and Management - ISSN 2371-7742, 2, 7-16. 